\title{
Pediatric Fractures Secondary to Trampoline Injury: A Prospective Analysis of User Circumstances and Injury Severity with Respect to American Academy of Pediatrics Policy Statement
}

\author{
Çocukluk Çağında Trampolin Yaralanmasına İkincil Gelişen Kırıklar: Kullanıcı Şartlarının ve \\ Yaralanma Şiddetinin Amerikan Pediyatri Akademisi Faaliyet Raporuna göre \\ Illeriye Yönelik Analizi
}

\author{
Christine Ho1, James Phelps², Neil Evans³, Pam Okada4, Philip Wilson1 \\ ${ }^{1}$ Texas Scottish Rite Hospital For Children, Clinic of Orthopedic Pediatric Surgery, Texas, USA \\ 2Southeastern Sports Medicine, Clinic of Orthopedic Surgery, Asheville, USA \\ ${ }^{3}$ Cook Children's Medical Center, Clinic of Pediatric Emergency Medicine, Texas, USA \\ ${ }^{4}$ University of Texas Southwestern Medical Center, Department of Pediatric Emergency, Texas, USA
}

\section{Abstract}

Introduction: The purpose of this study was to prospectively analyze injury patterns and severity with respect to American Academy of Pediatrics/Council on Sports Medicine and Fitness (AAP/CSMF) safety guidelines, and to report parental safety-awareness and behavior.

Methods: Two hundred ninety-nine consecutive patients were enrolled. Measures of severity included the abbreviated injury scale (AIS), and need for sedated procedure/surgery. Risk factors were defined by the AAP/CSMF recommendations.

Results: Of the 299 patients, 99\% (296/299) had severe/serious or moderate AIS scores. 49\% (147/299) required a surgical intervention or sedation-assisted fracture manipulation. An adult was present during $72 \%(214 / 299)$ of injuries, and 55\% (164/299) of injuries occurred with use of protective safety devices. $86 \%(255 / 299)$ of injuries occurred with multiple children on the trampoline. 42\% (126/299) of injuries occurred in children less than 6 years of age, and a high-risk maneuver was attempted in 23\% (70/299). Children less than 6 years old did not sustain more severe injuries compared to older children $(p=0.81)$. Paradoxically, having less children on the trampoline correlated to sustaining more severe injuries $(p=0.03) .83 \%(248 / 299)$ of parents reported awareness of the dangers of trampolines prior to their child's injury.

Conclusion: This study reinforces the AAP/CMSF discouragement of home trampoline use, multiple jumpers, and younger children. Safety equipment, avoidance of high-risk maneuvers, parental supervision, and parental awareness of trampoline dangers did not decrease injury severity. There is no such thing as "safe" trampolining, and severe injuries occur despite the best vigilance of parents.

Keywords: Trampoline, pediatric, injury, fracture

\section{Öz}

Amaç: Bu çalışmanın amacı Amerikan Pediyatri Akademisi/Spor Hekimliği ve Fitness Konseyi (APA/SHFK) güvenlik kılavuzuna göre yaralanma biçimlerinin ve şiddetinin ileriye yönelik analizi ve ebeveynlerin güvenlik farkındalığının ve davranışının raporlanmasıdır.

Yöntemler: Ardışık olarak 299 hasta çalışmaya alındı. Yaralanma şiddetinin ölçümü kısaltılmış yaralanma ölçeği (KYÖ) ve sedasyon altında yapılacak işlem/ameliyat gereksinimine göre yapıldı. Risk faktörleri APA/ SHFK önerilerine göre tanımlandı.

Bulgular: Iki yüz yirmi dokuz hastanın \%99'u (296/299) şiddetli/ciddi veya orta KYÖ skoruna sahipti. Hastaların \%49'unda (147/299) cerrahi müdahaleye veya sedasyon altında yapılan kırık manipülasyonuna intiyaç duyuldu. Çocukların \%72'sinin yaralandığı sırada yanlarında bir yetişkin bulunmaktaydı ve yaralanmaların \%55'i (164/299) koruyucu güvenlik araçları kullanıırken gerçekleşti. Yaralanmaların \%86'sı (255/299) trampolin üzerinde birden fazla çocuk varken gerçekleşti. Yaralanmaların \%42'si (126/299) 6 yaşından küçük çocuklarda görüldü ve \%23'ünde (70/299) çocuklar yüksek riskli bir manevra denemişti. Altı yaşın altındaki çocuklar yaşça büyük çocuklarla karşılaştııılı̆̆ında daha şiddetli yaralanmalara dayanamadı $(p=0,81)$. Çelişkili bir şekilde, trampolin üzerinde daha az çocuk bulunması daha şiddetli yaralanmalara dayanabilme ile ilişkiliydi $(p=0,03)$. Hastaların \%83'ü $(248 / 299)$ yaralanmanın öncesinde trampolinlerin tehlikelerinin farkında olduklarını belirtti.

Sonuç: Bu çalışma APA/SHFK'nin ev tipi trampolin kullanımını ve trampolini birden fazla kişinin ve küçük çocukların kullanımını teşvik etmeyen görüşlerini desteklemektedir. Güvenlik ekipmanları, yüksek riskli manevralardan kaçınmak, ebeveyn gözetimi ve ebeveynlerin trampolinlerin tehlikelerinin farkında olması gibi durumlarda bile yaralanma şiddetini azalmadı. Trampolinlerin "güvenli" kullanımı gibi bir durum söz konusu değildir ve şiddetli yaralanmalar ebeveynlerin en dikkatli olduğu durumlarda bile gerçekleşebilir.

Anahtar Kelimeler: Trampolin, çocuk, yaralanma, kırık 


\section{Introduction}

Trampolines were originally invented to assist the Eskimos with hunting game animals by launching young children high into the air to look for animals in the far distance. ${ }^{1}$ In 1936, George Nissen patented the trampoline for recreation and competition. 2 Since that time, the popularity of trampolining has waxed and waned, but has always had associated risks of serious injury, including but not limited to spinal cord injury and paralysis. ${ }^{2}$ In fact in 1971, the National Collegiate Athletic Association gymnastics committee determined that the risks of trampoline injury were unacceptable and removed it from national competition and training, but reinstated the trampoline for training in 1978.

The popularity of recreational trampoline use continues to escalate, and trampoline-related injuries remain common.2,3 According to the National Electronic Injury Surveillance System (NEISS), from 2004 to 2011 there was an estimated 1.002.735 emergency department (ED) visits for trampolinerelated injuries in children. ${ }^{4}$ Several recent studies confirm high injury rates despite safety recommendations, and the impact of the growing commercial trampoline recreational park is yet to be realized. 4-8

Most recently, The American Academy of Pediatrics (AAP) and the Council on Sports Medicine and Fitness (CSMF) released an updated policy statement summarizing reported trampoline injuries and subsequent safety recommendations. 9 The prior AAP policy statement had been released in 1999.10 From 2004 to 2009, overall injury incidence has decreased, but the annual injury rate remains greater than 30 per 100.000 , and severity remains significant. 9 Orthopedic and lower extremity injuries remain most common, and individuals less than 6 years of age appear to be at increased risks for fractures and joint injuries. Based upon assimilated data, this policy statement set forth the following safety recommendations: Trampoline use should be restricted to solo use; adult supervision is required; all safety equipment (padding, netting, level or ground-level use) should be utilized and maintained, and somersaults and flips should not be allowed.

The purpose of this study was to prospectively analyze injury patterns and severity with respect to AAP safety guidelines, and to report parental safety-awareness and behavior in regards to patients presenting for treatment of trampolinerelated injuries to a level 1 pediatric trauma center.

\section{Materials and Methods}

\section{Study Design and Population}

From December 2007 to April 2010, all consecutive patients seen in the pediatric ED or orthopedic clinic at a level 1 pediatric trauma center, who sustained a reported trampoline-related injury, were identified. Our ED has an annual volume of ranging from 110.000 to 125.000 patients. Families were approached in the area of care delivery for questionnaire explanation and completion by an independent research coordinator. The questionnaire evaluated the physical environment and circumstances leading up to the injury, such as the mechanism of injury, characteristics of the trampoline, circumstances surrounding the injury event, and the environment surrounding the trampoline. Use of trampoline protective gear (nets, pads, spring covers) was also documented. Patients were excluded if the family elected not to participate in questionnaire completion. This study was approved by the institutional review board and the patient's legal guardian provided informed consent to participate. The patient's medical record was reviewed for demographic information and treatment course.

Using the guidelines defined by the AAP in 2009 and again in 2012, as well as the CSMF, we determined prospectively our definition of risk factors for severity of injury. These were defined as: (1) the presence of adult supervision, (2) use of protective safety devices, (3) high-risk maneuver performed at the time of injury, (4) trampoline height, (5) number of participants and size/weight of participant(s) on the trampoline, and (6) age of the patient. The severity of injury was measured by the abbreviated injury scale (AIS), the need for surgical treatment, and the need for a sedation-assisted closed reduction with manipulation of the fracture. The AIS, an anatomical scoring system for ranking severity of injury from 1 (minor) to 6 (unsurvivable), has been well described and validated for classifying injury severity in children (Appendix 1).11,12 Given the paucity of multi-system injuries in our patent population, the AIS was selected over the Injury Severity Score to measure the traumatic injury.

\section{Survey Content and Administration}

Survey questions were created based on published warnings and guidelines from the AAP/CSMF, recommendations from the US Consumer Product Safety Commission, the International Trampoline Industry Association, as well as risk factors associated with trampoline injuries as detailed by previously published studies. Survey questions intended

\section{Appendix 1.}

Abbreviated injury scale-anatomical scoring system for ranking severity of injury. Injuries ranked from scale 1-6:
- 1 Minor
- 2 Moderate
- 3 Serious
- 4 Severe
- 5 Critical
- 6 Unsurvivable 
to better define frequency of use of the trampoline as well as family experience with trampoline use and awareness of possible associated risks were also included. 9

The paper survey was filled out by the parent after being approached in either the ED or the orthopedic clinic once the child had been identified as having sustained a trampoline injury and the parent consented to participation. The research coordinator was available for questions and clarification, but the survey was completed independently by the parent. Surveys translated in Spanish were available for our Spanishspeaking families.

No prior validation or testing of the questionnaire was done prior to administration of the survey at the inception of study enrollment.

\section{Data Analysis}

Analysis was performed on data collected using SAS version 9.2. A two-sample t-test was used to compare continuous variables to severity of injury. For categorical variables, a chisquare test was used. Univariate analysis of each risk factor was performed as a screening for possible further multivariate logistic regression analysis; if none were significant in the univariate analysis, no logistic regression would be run, as a probability of finding statistical significance would be extremely low. Statistical significance was defined as $p<0.05$.

\section{Results}

A total of 300 (three hundred) patients who sustained a trampoline-related injury were identified. One patient did not complete the questionnaire, leaving 299 patients eligible for this study. Of the 299 patients, 95 were enrolled from the ED, and 204 patients were enrolled after being evaluated in the orthopaedic clinic. Patient demographics and injury characteristics are summarized in Table 1. The ethnic distribution of patients enrolled in our study is comparable to our distribution in the ED where $57 \%$ of patients identify themselves as "Hispanic", 27\% as "black", 9\% as "white", and $7 \%$ as "other." In our orthopaedic clinic, 52\% of the patients identify themselves as "Hispanic", 47\% identify themselves as "non-Hispanic", and 1\% select "Refused/Unknown".

Of the injuries, 91\% were fractures (273/299), 7\% (20/299) were soft tissue injuries such as joint sprains, $0.7 \%(2 / 299)$ were facial injuries, 1\% (3/299) were visceral injuries, and one patient did not suffer diagnosable injury (Table 2). $42 \%$ $(126 / 299)$ of the injuries occurred in patients less than 6 years of age. In this younger age group, $97 \%(122 / 126)$ of these injuries were fractures.

With regards to injury severity data, no patient had a score of 5 (critical) or 6 (unsurvivable) as measured by the AIS. As measured by the AIS, $99 \%$ of the injuries were classified as moderate or severe/serious injuries, and in fact, almost half of all injuries were classified as severe or serious (Table 3 ). The patients were analyzed by grouping those less than 6 years of age compared by those more than 6 years of age, as per the AAP recommendations. 9 In our cohort, patients less than 6 years of age were not more likely to sustained severe/serious injuries, as graded by the AIS $(p=0.81)$. When grouping patients into those less than 11 years of age compared to those 11 years of age and older, there was again no difference in the incidence of serious/severe injuries as graded by the AIS ( $p=0.34$ ) (Table 4). Of our enrolled cohort, $48 \%(143 / 299)$ of patients required a procedure or surgery to treat their injuries, with 30\% (91/299) undergoing procedural sedation to treat their orthopaedic injury and 17\% (52/299)

\section{Table 1. Patient and injury demographics $(\mathbf{n}=\mathbf{2 9 9})$}

\begin{tabular}{ll} 
Age, median (interquartile range), years & $6.0(4.0-9.0)$ \\
Male, n/N (\%) & $180 / 299(60 \%)$ \\
Race, n/N (\%) & \\
White & $102 / 299(34 \%)$ \\
Hispanic & $179 / 299(60 \%)$ \\
Black & $14 / 299(5 \%)$ \\
Asian & $4 / 299(1 \%)$ \\
Seasonal distribution, n/N (\%) & \\
Spring & $149 / 299(50 \%)$ \\
Summer & $51 / 299(17 \%)$ \\
Fall & $39 / 299(13 \%)$ \\
Winter & $60 / 299(20 \%)$ \\
\hline
\end{tabular}

Table 2. Distribution of diagnosis from trampoline injuries

\begin{tabular}{ll|}
\hline Diagnosis & Frequency n=299 (percent) \\
Elbow fracture & $101(34 \%)$ \\
Forearm fracture & $69(21 \%)$ \\
Tibia/Fibula fracture & $44(15 \%)$ \\
Ankle fracture & $21(7 \%)$ \\
Joint sprain & $14(5 \%)$ \\
Femur fracture & $12(4 \%)$ \\
Hand fracture & $8(3 \%)$ \\
Humerus fracture & $8(3 \%)$ \\
Cervical sprain & $6(2 \%)$ \\
Foot fracture & $5(2 \%)$ \\
Visceral injury & $3(1 \%)$ \\
Patella fracture & $2(0.7 \%)$ \\
Clavicle fracture & $2(0.7 \%)$ \\
Facial injury & $2(0.7 \%)$ \\
Spine fracture & $1(0.3 \%)$ \\
No injury & $1(0.3 \%)$ \\
\hline
\end{tabular}


required operative intervention for fixation of their fracture or injury. When grouping by age, there was no statistically significant relationship between patient age and the need for a procedure or surgery (Table 5).

Results of the questionnaire are shown in Table 6. Upon analysis with respect to AAP/CSMF guidelines:

\section{- Recommendation for solo use:}

The vast majority of the injuries (86\%, 255/299) occurred with more than one child on the trampoline, and 19\% $(58 / 299)$ of the injuries were sustained when there were 5 children or more on the trampoline at the time of injury. An adult was actually jumping on the trampoline with the child in 3\% (8/299) of the injuries. Information regarding number of jumpers was not available in 3 patients.

\section{- Adult supervision:}

Adult supervision, defined as a person greater than 18 years of age who was actively watching the patient on the trampoline while in proximity to the trampoline (i.e., not indoors while the child was outdoors), was present during 72\% (214/299) of the injuries.

\section{- Use of safety equipment:}

Protective gear, such as padding, netting, or spring covers, was present on 55\% (163/299) of the trampolines.

\section{- Avoidance of somersaults and flips:}

A high-risk maneuver (flip, jump from an elevated surface onto the trampoline, etc.) was being performed in 23\% (70/299)

\section{Table 3. Distribution of abbreviated injury scale}

\section{AIS}

No/minor injury (score 0-1)

Moderate injury (score 2)

Serious/severe injury (score 3-4)

AIS: Abbreviated injury scale of the injuries. Only 1 of these injuries sustained during a high risk maneuver was rated minor by the AIS, 35 injuries were moderate, and 34 injuries were ranked as serious. In our cohort, $30 \%(21 / 70)$ of these injuries required operative treatment, $19 \%(13 / 70)$ required a sedation-assisted closed reduction with manipulation of the fracture, and $51 \%(36 / 70)$ were treated nonoperatively (i.e., with casting or splinting).

There was no correlation between risk factors and severity, except that having less children on the trampoline was statistically associated with sustaining a more severe injury $(p=0.03)$ (Table 7$)$. Almost half $(45 \%, 19 / 42)$ of the single jumpers were performing a high-risk maneuver at the time of injury while only 20\% (50/255) of multiple jumpers were performing a high-risk maneuver when they were injured.

Parental awareness and behavior data revealed that 4\% $(13 / 299)$ of the injured children had been previously injured on a trampoline, and 13\% (40/299) of respondents reported that another family member had been previously injured on a trampoline. The majority of parents (83\%, 248/299) reported that they were aware of the dangers associated with trampolining prior to their child's injury, and 57\% (171/299) stated that they would not allow their child on a trampoline in the future.

\section{Conclusions}

Consistent with AAP/CSMF reported data, the majority of injuries in our series were orthopedic in nature. However, in our series, $91 \%$ were fractures as opposed to less than $50 \%$ fractures across all age groups in NEISS data. This may be a reflection of both the type of patient presenting and transferring to a tertiary urban center as opposed to pooled multi-center data as well as bias due to $68 \%$ of patients (204/299) being enrolled through the orthopaedic clinic. Although we attempted to identify and enroll all patients

Table 4. Patient age compared to abbreviated injury scale

\begin{tabular}{|llll}
\hline & AIS mild/moderate & AIS severe/serious & p value \\
Patient age $<6$ years & $0-5$ years & $50 \%(63 / 126)$ & $50 \%(62 / 126)$ \\
Patient age $<11$ years & 6 years and older & $51 \%(89 / 173)$ & $49 \%(84 / 173)$ \\
AIS: Abbreviated injury scale & $0-10$ years & $50 \%(126 / 254)$ & $50 \%(128 / 254)$ \\
\hline
\end{tabular}

Table 5. Patient age compared to rate of procedures/surgery

\begin{tabular}{|lllll|}
\hline & & Procedure/Surgery & No procedure & p value \\
Patient age $<6$ years & $0-5$ years & $49 \%(62 / 126)$ & $51 \%(64 / 126)$ & 0.68 \\
Patient age $<11$ years & 6 years and older & $47 \%(81 / 173)$ & $49 \%(125 / 254)$ & $51 \%(129 / 254)$ \\
\hline
\end{tabular}




\section{Table 6. Questionnaire-responses in bold}

\section{Mechanism of injury:}

Fall from trampoline

$19.1 \%(57 / 299)$

Fall on trampoline

$36.5 \%(109 / 299)$

Air collision with another person

$6 \%(18 / 299)$

Dismounting from trampoline

$4 \%(12 / 299)$

Flip/Handstand on trampoline

$9 \%(27 / 299)$

Contact with frame/Spring

$2.7 \%(8 / 299)$

Injury from high platform jump on to the trampoline (i.e. Jump from roof on to the trampoline)

$1.7 \%(5 / 299)$

Landed upon from another person on the trampoline

$11.7 \%(35 / 299)$

Unknown

$0.3 \%(1 / 299)$

Other

$0.9 \%(27 / 299)$

\section{Place of injury:}

Patient's home

$44.8 \%(134 / 299)$

Friend's home

$34.5 \%(103 / 299)$

Relative's home

$18.7 \%(56 / 299)$

Sport Facility

$0.3 \%(1 / 299)$

Gymnasium

$0.7 \%(2 / 299)$

School

$0.3 \%(1 / 299)$

Playground

$0 \%(0 / 299)$

Other

$0.7 \%(2 / 299)$

\section{At what age did you allow your child on a trampoline for the first time?}

\section{Age}

0-12 months

1\% (3/299)

1-5 years

$73 \%(217 / 299)$

6-10 years

$23 \%(68 / 299)$

10-15 years

$4 \%(11 / 299)$

\section{Trampoline size:}

Circular diameter

$<6 \mathrm{ft}$

$4 \%(12 / 299)$

$6 \mathrm{ft}-10 \mathrm{ft}$

$32 \%(97 / 299)$

11-16ft

$47 \%(141 / 299)$

$>16 \mathrm{ft}$

$11 \%(34 / 299)$

\section{Rectangle}

$8 \times 8 \mathrm{ft}$

$0.4 \%(1 / 299)$

$8 \times 10 f t$

$0.4 \%(1 / 299)$

$8 \times 14 \mathrm{ft}$

$0.4 \%(1 / 299)$

$8 \times 16 \mathrm{ft}$

$0.4 \%(1 / 299)$

$9 \times 16 \mathrm{ft}$

$0.4 \%(1 / 299)$

$11 \times 14 \mathrm{ft}$

$1.1 \%(3 / 299)$

$14 \times 16 \mathrm{ft}$

$1.1 \%(3 / 299)$

Other

$1.3 \%(4 / 299)$

What is the height of the trampoline?

$<2 \mathrm{ft}$ 


\begin{tabular}{|c|c|}
\hline \multicolumn{2}{|c|}{ When did you buy your trampoline? } \\
\hline$<1$ month & $3 \%(9 / 299)$ \\
\hline 1-6 months & $8.4 \%(25 / 299)$ \\
\hline $1-5$ years & $29 \%(86 / 299)$ \\
\hline $5-10$ years & $3.3 \%(10 / 299)$ \\
\hline \multicolumn{2}{|c|}{ How often do you check for repairs? } \\
\hline Every day & $4.7 \%(14 / 299)$ \\
\hline More than once a week & $14.7 \%(44 / 299)$ \\
\hline Once a week & 0\% (0/299) \\
\hline Do not own a trampoline & $49.8 \%(149 / 299)$ \\
\hline \multicolumn{2}{|c|}{ How often is your trampoline used? } \\
\hline Everyday & $20.1 \%(60 / 299)$ \\
\hline 3 times per week & $13.7 \%(41 / 299)$ \\
\hline Once a week & $13.7 \%(41 / 299)$ \\
\hline Once a month & $2.7 \%(8 / 299)$ \\
\hline Once per year & 0\% (0/299) \\
\hline Do not own a trampoline & $49.8 \%(149 / 299)$ \\
\hline \multicolumn{2}{|c|}{ What is the average time spent per use? } \\
\hline$<15 \min$ & $50.7 \%(152 / 299)$ \\
\hline $15-30 \min$ & $29.4 \%(88 / 299)$ \\
\hline $30-60 \mathrm{~min}$ & $11.7 \%(35 / 299)$ \\
\hline $1-2$ hours & $5.3 \%(16 / 299)$ \\
\hline$>2$ hours & $2.4 \%(7 / 299)$ \\
\hline Unknown & $0.4 \%(1 / 299)$ \\
\hline \multicolumn{2}{|c|}{ What was the number of children on the trampoline when your child was injured? } \\
\hline \multicolumn{2}{|l|}{ \# Children } \\
\hline 1 & $14.1 \%(42 / 299)$ \\
\hline 2 & $23.6 \%(70 / 299)$ \\
\hline 3 & $28 \%(83 / 299)$ \\
\hline 4 & $15 \%(44 / 299)$ \\
\hline 5 & $11 \%(33 / 299)$ \\
\hline $6-12$ & $8 \%(25 / 299)$ \\
\hline Unknown & $0.7 \%(2 / 299)$ \\
\hline \multicolumn{2}{|c|}{ Was a high risk maneuver attempted when your child was injured? } \\
\hline Yes & $23.4 \%(70 / 299)$ \\
\hline No & $76.6 \%(229 / 299)$ \\
\hline
\end{tabular}




\begin{tabular}{|c|c|}
\hline \multicolumn{2}{|c|}{ Where is the trampoline located? } \\
\hline Middle of backyard & $66.7 \%(200 / 299)$ \\
\hline Close to house & $16.7 \%(50 / 299)$ \\
\hline Close to pool & $0.3 \%(1 / 299)$ \\
\hline Close to swing set & $0.7 \%(2 / 299)$ \\
\hline Concrete & $1 \%(3 / 299)$ \\
\hline Grass & $86 \%(257 / 299)$ \\
\hline Dirt & $11.7 \%(35 / 299)$ \\
\hline Gravel & $0.3 \%(1 / 299)$ \\
\hline \multicolumn{2}{|c|}{ Does the trampoline have protective gear? (Numbers do not equal 299 due to multiple answers selected) } \\
\hline Netting & $34.8 \%(104 / 299)$ \\
\hline Padding & $39.1 \%(11 / 299)$ \\
\hline Spring covers & $29.4 \%(88 / 299)$ \\
\hline Unknown & $1 \%(3 / 299)$ \\
\hline None & $44.5 \%(133 / 299)$ \\
\hline \multicolumn{2}{|c|}{ Was your child wearing any protective gear? } \\
\hline Yes & $0 \%(0 / 299)$ \\
\hline No & $100 \%(299 / 299)$ \\
\hline Contusions & $0 \%(0 / 14)$ \\
\hline Lacerations & $14 \%(2 / 14)$ \\
\hline Abdominal & $0 \%(0 / 14)$ \\
\hline Head injuries & $0 \%(0 / 14)$ \\
\hline Broken bone, fracture & $50 \%(7 / 14)$ \\
\hline Sprains/Strains & $35.7 \%(5 / 14)$ \\
\hline Spine injuries & $0 \%(0 / 14)$ \\
\hline Other & $0 \%(0 / 14)$ \\
\hline \multicolumn{2}{|c|}{ Has anyone else in your family had a trampoline injury? } \\
\hline Yes & $13 \%(40 / 299)$ \\
\hline No & $87 \%(259 / 299)$ \\
\hline \multicolumn{2}{|c|}{ Were you aware of the dangers of a trampoline? } \\
\hline Yes & $83 \%(248 / 299)$ \\
\hline No & $17 \%(51 / 299)$ \\
\hline \multicolumn{2}{|c|}{ Will you continue to allow your children to participate on a trampoline? } \\
\hline Yes & $31.4 \%(94 / 299)$ \\
\hline No & $57.2 \%(171 / 299)$ \\
\hline Maybe & $11.4 \%(34 / 299)$ \\
\hline
\end{tabular}


presenting to our ED with trampoline use as mechanism of injury, the majority of patients were identified through our orthopaedic fracture clinic, skewing the types of injuries seen in this cohort. However, our results are consistent with that of the study by Eberl et al. ${ }^{13}$ which found that $40 \%$ of injuries were severe (defined in that series as any fracture or ligament rupture). Furthermore, the authors found that use of a trampoline was associated with a significant risk of bodily harm at any age. 13

The preponderance of injuries in the spring season might be attributed to milder weather in our geographic location; in our area, summer temperatures commonly exceed $38^{\circ}$ Celsius for multiple months, leading to heat advisories from the National Weather Service that limits outdoor play. Colder weather in the winter also discourages children from playing outdoors, and may limit trampoline use during winter months.

The NEISS data and the AAP/CSMF policy suggest that children younger than 6 years of age are at a possible risk for higher severity injuries (defined as fractures as opposed to soft tissue). While our series showed this age group to be a significant percentage of overall injured children $(42 \%$
$(126 / 299)$ of the injuries occurred in patients less than 6 years of age), when using an injury severity score as a more definitive measure of severity, we found that patient age less than 10 years was significant for more severe injury as measured by the AIS $(p<=0.045)$. The stated risk factors of no adult supervision, absence of safety equipment, and flip maneuvers were not found to be associated with increased severity of injury in this study. Interestingly, while the majority of injuries occurred with multiple jumpers, the presence of a lesser number of children was associated with higher injury severity as measured by AIS. While surprising, almost half of the children who were the sole jumper on the trampoline were injured while performing a high risk maneuver such as a backflip or other gymnastic maneuver. It may be postulated that children who are on the trampoline by themselves may feel emboldened to perform riskier maneuvers than those children who are jumping with multiple jumpers, or that jumpers of higher skill level jump alone and may more commonly attempt high-risk maneuvers.

With regards to AAP/CMSF safety recommendations, the most significant possible reduction in injury could have been

Table 7. Relationship between abbreviated injury scale and risk factors ( ${ }^{*}$ Numbers do not all add to 299 due to missing responses)

\begin{tabular}{|c|c|c|c|c|}
\hline & & AIS Mild/Moderate & AIS Severe/Serious & p value \\
\hline \multirow{2}{*}{ Adult supervision } & Yes & $50 \%(107 / 214)$ & $50 \%(107 / 214)$ & \multirow{2}{*}{0.71} \\
\hline & No & $52 \%(44 / 84)$ & $48 \%(40 / 84)$ & \\
\hline \multirow{2}{*}{ Protective safety devices } & Yes & $51 \%(84 / 164)$ & $49 \%(80 / 164)$ & \multirow{2}{*}{0.74} \\
\hline & No & $49 \%(65 / 132)$ & $51 \%(67 / 132)$ & \\
\hline \multirow{2}{*}{ High risk maneuver } & Yes & $51 \%(36 / 70)$ & $48 \%(34 / 70)$ & \multirow{2}{*}{0.91} \\
\hline & No & $51 \%(116 / 229)$ & $49 \%(113 / 229)$ & \\
\hline \multirow{3}{*}{ Trampoline height } & $<2$ feet & $14 \%(1 / 7)$ & $86 \%(6 / 7)$ & \multirow{3}{*}{0.15} \\
\hline & 2-4 feet & $52 \%(149 / 288)$ & $48 \%(139 / 288)$ & \\
\hline & $>4$ feet & $50 \%(2 / 4)$ & $50 \%(2 / 4)$ & \\
\hline \multicolumn{2}{|c|}{$\begin{array}{l}\text { Mean number of children on trampoline } \\
\text { (standard dev) }\end{array}$} & $3.45( \pm 1.94)$ & $2.99( \pm 1.64)$ & 0.03 \\
\hline \multicolumn{2}{|c|}{$\begin{array}{l}\text { Mean total weight of all children on trampoline, } \\
\text { estimated by family }(\mathrm{kg}) \text { (standard dev) }\end{array}$} & $92.15( \pm 48.7)$ & $87.17( \pm 54.4)$ & 0.46 \\
\hline \multicolumn{2}{|c|}{ Mean patient BMI (standard deviation) } & $18.3( \pm 4.4)$ & $17.8( \pm 4.3)$ & 0.30 \\
\hline \multirow{2}{*}{ Years trampoline owned } & $<1$ year & $56 \%(30 / 54)$ & $44 \%(24 / 54)$ & \multirow{2}{*}{0.34} \\
\hline & $>1$ year & $45 \%(43 / 96)$ & $55 \%(53 / 96)$ & \\
\hline \multirow{2}{*}{ Prior trampoline injury } & Yes & $54 \%(7 / 13)$ & $46 \%(6 / 13)$ & \multirow{2}{*}{0.82} \\
\hline & No & $51 \%(145 / 286)$ & $49 \%(141 / 286)$ & \\
\hline \multirow{2}{*}{$\begin{array}{l}\text { Family member with prior } \\
\text { trampoline injury }\end{array}$} & Yes & $45 \%(18 / 40)$ & $55 \%(22 / 40)$ & \multirow{2}{*}{0.43} \\
\hline & No & $52 \%(134 / 259)$ & $48 \%(125 / 259)$ & \\
\hline \multirow{3}{*}{ Trampoline size, diameter (ft) } & $<6$ & $58 \%(7 / 12)$ & $42 \%(5 / 12)$ & \multirow{3}{*}{0.36} \\
\hline & $6-10$ & $56 \%(55 / 98)$ & $44 \%(43 / 98)$ & \\
\hline & $>10$ & $48 \%(86 / 180)$ & $52 \%(94 / 180)$ & \\
\hline
\end{tabular}


seen by following the recommendation for solo use. $86 \%$ of injuries in our study occurred with more than one child on the trampoline. This number is identical with the report by Rättyä and Serlo ${ }^{14}$ that also documented multiple jumpers in $86 \%$ of cases (57/76 patients). However, over half of our families reported safety equipment present on trampolines $(55 \%)$, and the majority (77\%) of injuries occurred in nonflipping activities-suggesting that reduction in injury incidence may not be as significant by increasing compliance with these recommendations. Finally, with regards to adult supervision, $72 \%$ of injuries were reported to occur when adult supervision was present. This finding seems to contradict the recommendation that adult supervision is an important safety measure. As injuries can occur in an instant, it is unlikely that an adult watching a child on a trampoline can act quickly enough to prevent an impending injury.

Responses surrounding parental awareness and behavior provide some possible insight for future injury prevention and safety campaigns. The vast majority (83\%) of parents reported that they were aware of the dangers associated with trampolining prior to their child's injury. As a result of this event, over half (57\%) stated that they would not allow their child on a trampoline in the future. While that may be expected in some parents, the survey also supplied some data that may suggest repeated use and possible repeated unsafe behavior can be expected-17\% of respondents reported that the same child or another family member had been previously injured on a trampoline. As most parents report prior knowledge of safety risks and there was significant incidence of repeat injury, a more bold, concise, and direct messaging campaign may be required.

Limitations to this study include sample bias, as these are patients who present to a tertiary level I center, and this study may exclude lesser injuries that did not present to a tertiary referral center. In addition, self-reported data may not be accurate with respect to true injury circumstances and safety equipment, and some parents did not know the exact circumstance of their child's injury. Our study population is biased for orthopaedic injuries, as $68 \%$ of our patients were identified through the orthopaedic clinic, with $91 \%$ of patients sustaining fractures. Recent NEISS data report a $29 \%$ fracture rate, and therefore our cohort may not be applicable to a population evaluated in other settings. ${ }^{14}$

This study is consistent with the epidemiologic study done by Smith and Shields in 1998 that called for the abandonment of trampoline use as a backyard activity. 15 Our findings support a policy banning trampoline use in the home setting, as almost all of our injuries occurred during home trampoline use. Trampoline manufacturers targeting family consumers extol the virtues of their safety designs, which are in line with AAP recommendations, yet these safety devices did not decrease severity of injury in this study.

In consideration of AAP/CSMF guidelines, the large majority of injuries occurred with multiple users jumping. Additionally, more than $70 \%$ of injuries occurred in the setting of parental supervision. However, adult supervision, use of safety devices, avoidance of high-risk maneuvers, and higher number and size of participants were not associated with less severe injuries.

In order to focus on public awareness and safety campaigns, a more concise message targeting the concept of solo use only as well as the increased risk in children less than 10 years of age may be useful to reduce overall injury incidence. However, our data suggest that repeated use of the trampoline and unsafe behavior can be expected despite warnings, as $17 \%$ of respondents reported a previous trampoline injury in the same child or a family member, and $83 \%$ affirmed that they were aware of the dangers associated with trampolines prior to the injury. Children are at risk for serious injuries when participating in trampoline recreation regardless of age. Ultimately, our results demonstrate that, despite following AAP recommended guidelines, there is no such concept as "safe trampolining" at home, and severe injuries occur despite the best vigilance of parents.

\section{Ethics}

Ethics Committee Approval: IRB approval from the institution was obtained, Informed Consent: Not required due to retrospective study,

Peer-review: External and Internal peer-reviewed.

\section{Authorship Contributions}

Surgical and Medical Practices: Christine Ho, James Phelps, Neil Evans, Pam Okada, Philip Wilson, Concept: Christine Ho, Philip Wilson, Design: Christine Ho, James Phelps, Pam Okada, Neil Evans, Data Collection or Processing: James Phelps, Neil Evans, Analysis or Interpretation: James Phelps, Christine Ho, Literature Search: James Phelps, Christine Ho, Philip Wilson, Writing: James Phelps, Christine Ho, Philip Wilson, Pam Okada.

Conflict of Interest: No conflict of interest was declared by the authors.

Financial Disclosure: The authors declared that this study received no financial support.

\section{References}

1. Levine D. All-terrain vehicle, trampoline and scooter injuries and their prevention in children. Curr Opin Pediatr. 2006;18:260-5. 
2. Esposito PW, Esposito LM. The reemergence of the trampoline as a recreational activity and competitive sport. Curr Sports Med Rep. 2009;8:273-7.

3. Bhangal KK, Neen D, Dodds R. Incidence of trampoline related pediatric fractures in a large district general hospital in the United Kingdom: Lessons to be learnt. Inj Prev. 2006;12:133-4.

4. Loder RT, Schultz W, Sabatino M. Fractures from trampolines: Results from a national database, 2002 to 2011. J Pediatr Orthop. 2014;34:683-90.

5. Furnival RA, Street KA, Schunk JE. Too many pediatric trampoline injuries. Pediatrics. 1999;103:57.

6. Hurson C, Browne K, Callender O, O'Donnell T, O'Neill A, et al. Pediatric trampoline injuries. J Pediatr Orthop. 2007;27:729-32.

7. Linakis JG, Mello MJ, Machan J, Amanullah S, Palmisciano LM. Emergency department visits for pediatric trampoline-related injuries: An update. Acad Emerg Med. 2007;14:539-4.

8. Nysted $\mathrm{M}$, Drogset JO. Trampoline injuries. $\mathrm{Br} J$ Sports Med. 2006;40:984-7.
9. Council on Sports Medicine and Fitness, American Academy of Pediatrics, Briskin S, LaBotz M. Trampoline safety in childhood and adolescence. Pediatrics. 2012;130:774-9.

10. Trampolines at home, school, and recreational centers. American Academy of Pediatrics. Committee on Injury and Poison Prevention and Committee on Sports Medicine and Fitness. Pediatrics. 1999;103:1053-6.

11. Association for the Advancement of Automotive Medicine: Abbreviated Injury Scale 2005 Update 2008. http://www.aaam.org/ about-ais.html. Accessed June 4, 2014.

12. Durbin DR, Localio AR, MacKenzie EJ. Validation of the ICD/AIS MAP for pediatric use. Inj Prev. 2001;7:96-9.

13. Eberl R, Schalamon J, Singer G, Huber SS, Spitzer P, et al. Trampolinerelated injuries in childhood. Eur J Pediatr. 2009;168:1171-4.

14. Rattya J, Serlo W. Using a safety net and following the safety instructions could prevent half the paediatric trampoline injuries. Eur J Pediatr Surg. 2008;18:261-5.

15. Smith GA, Shields BJ. Trampoline-related injuries to children. Arch Pediatr Adolesc Med. 1998;152:694-9. 